GEOGRAFICKÝ ČASOPIS / GEOGRAPHICAL JOURNAL 71 (2019) 3, 241-262

DOI: https://doi.org/10.31577/geogrcas.2019.71.3.13

\title{
HISTORICKÉ PRIEMYSELNÉ ŠTRUKTÚRY V MENIACEJ SA MESTSKEJ KRAJINE BRATISLAVY
}

\author{
Pavel Šuška* \\ * Geografický ústav SAV, Štefánikova 49, 81473 Bratislava, geogsusk@savba.sk
}

\begin{abstract}
Historical industrial structures in the changing urban landscape of the city of Bratislava

The aim of the article is to analyse the development and transformations of historical industrial structures in Bratislava from its beginnings in the second half of the $19^{\text {th }}$ century, through extensive urban growth of the socialist development until postsocialist urban transformations which once again brought newly redefined conditions of urban political economy. The historical industry is understood as elements of the built environment which, at the time of its formation (i.e. since the beginning of the industrial revolution in the city until the II World War), had manufacturing or closely related functions. The emergence and the following destinies of this part of the physical urban landscape is analysed through fluctuations of the values of sites and actual built structures affected by the political and economic changes or urban development transformations of the city itself.
\end{abstract}

Key words: historical industry, value, urban development, Bratislava, Slovakia

\section{ÚVOD}

Bratislava sa hrdí významnou industriálnou tradíciou. Na prelome 19. a 20. storočia malo mesto, vtedy nesúce iné mená, pozíciu druhého najpriemyselnejšieho mesta v Uhorsku. Neskôr v medzivojnovom období sa stala najpriemyselnejším mestom slovenskej časti Československa. Nájst' v súčasnej mestskej krajine materiálne dôkazy tejto minulosti je však čoraz tažšie. V článku bude predstavený príbeh fabrík a celých továrenských zón, ktoré zohrávali klúčcovú úlohu pri urbanistickom rozvoji Bratislavy najmä od poslednej tretiny 19. storočia, a o svoju ekonomickú funkciu väčšinou prišli až na sklonku storočia minulého. Osud mnohých budov pamätajúcich priemyselnú revolúciu $\mathrm{v}$ meste bol definitívne spečatený ich fyzickým odstránením len pomerne nedávno. Aj preto je na mieste hladat' mnohé z odpovedí na otázky pátrajúce po jeho príčinách práve $\mathrm{v}$ nastaveniach aktuálnych spoločenských vzt’ahov. Meniaca sa miestna ekonomická štruktúra, vyjadrujúca širšie zmeny v priestorovej del'be práce, investičná atraktivita a aktivita, charakteristiky trhu s nehnutel'nost'ami, postavenie pamiatkovej ochrany a podobne, pomôžu osvetlit' mnohé dôležité príciny nenávratného zániku historického industriálu. $\mathrm{Na}$ druhej strane viaceré, na prvý pohlad možno nie úplne zjavné, transformácie ovplyvňujúce osudy tejto historickej vrstvy boli spustené ovel’a skôr a rozhodne si zaslúžia bližšie preskúmanie. Preto sa pozornost' sústredí tiež na dávnejšiu minulost', ktorú reprezentuje už obdobie vzniku predmetnej vrstvy. Ide o obdobie rozvoja továrenskej vel'kovýroby, a s ňou spojenej urbanizácie konca 19. a prvej polovice 20. storočia. Rovnako dôležité je pochopit' zmeny, ktorými historický industriál i mesto prešli $\mathrm{v}$ neskorších obdobiach dynamickej urbanistickej premeny počas epochy štátneho socializmu. V štúdii najskôr predstavíme teoretickú perspektívu hodnoty a transformácie vybudovaného prostredia, pomocou ktorej bude d’alej interpretovaný príbeh bratislavského historického industriálu od svojich počiatkov po dnešok. 


\section{HODNOTA VYBUDOVANÉHO PROSTREDIA}

Pri uvažovaní o vybudovanom prostredí a mestskej krajine musíme začat' banálnou skutočnost'ou, že v princípe každá človekom vybudovaná hmotná štruktúra je odsúdená na zánik. Jednou z klúčových teórií, ktorá dáva nevyhnutnost' zmeny materiálnej krajiny do súvislosti so základnými vzt’ahmi spoločenského výrobného spôsobu, je teória produkcie racionálnej krajiny a kreatívnej deštrukcie (napr. Harvey 1985, 1989a a 1989b). Podl'a nej je vybudované urbánne prostredie podriadené neustálej zmene, pričom sa dostáva do centra jedného z rozporov procesu akumulácie kapitálu, ked' jeho kolobeh rovnako produkuje geografickú štruktúru cirkulácie, no $\mathrm{v}$ tom istom čase sa ňou stáva obmedzený.

Pôvodný argument rozvinul v kontexte reflexie vel'kej hospodárskej krízy ekonóm Schumpeter (1975), ked' vysvetl'oval cyklický charakter striedania vín rastu a úpadku, ktorému sú vystavené kapitalistické ekonomiky. V ňom tvrdil, že nevyhnutnost' dosahovania zisku či produkcie nadhodnoty vedie, okrem iného, k rozvoju nových technológií. Dôsledkom takéhoto investovania je nevyhnutné (morálne) zastarávanie nielen starších technológií, ale i inovácií od nich závislých. Reakciou priestorových ekonomík na priebeh dynamiky investičných cyklov je striedanie období rastu a úpadku. Pôvodný argument bol neskôr rozvinutý viacerými geografmi, významnou mierou napr. D. Harveym. Vo svojej teórii akumulácie (Harvey 1985, 1989a a 1989b) popísal proces produkcie "racionálnej krajiny" utváranej opakovanými sériami investícií, ktoré ostávajú často na vel’mi dlhý čas zhmotnené v danom mieste. S rozvojom a zmenou technológií a neustálym vyhladávaním zisku však racionálna krajina alebo priestorové riešenie minulosti predstavuje bariéru d’alšieho rozvoja. Táto je prekonaná procesom kreatívnej deštrukcie, ktorá klesajúcimi investíciami a znehodnotením existujúcich investícií lokalizovaných a ukotvených $\mathrm{v}$ priestore pripravuje pôdu pre nové investičné cykly, ked' staré znehodnotené je zničené, aby mohlo vyrást' nové. Ide tu teda o fundamentálne napätie medzi fixáciou a pohybom, ked' čast' investícii musí fungovat' v podobe fixovaného imobilizovaného kapitálu $\mathrm{v}$ konkrétnom mieste $\mathrm{v}$ procese produkcie, pričom si musia neustále uchovávat' úžitkové hodnoty (z hl'adiska produkcie), teda schopnost' pritahovat' cirkulujúci kapitál, ktorý cez ne prúdi v kolobehoch vlastnej reprodukcie.

Úžitková hodnota je klúčovou vlastnost'ou v človekom vytvorenej fyzickej krajine predstavujúcej systém zdrojov využitel'ných na produkciu, výmenu alebo spotrebu (Harvey 1985). Iba v jej realizácii, či očakávaní realizácie, môžu získat' komodity výmennú hodnotu, ktorá je vyjadrená pomerom, v akom je komodita vymieňaná za iné komodity. $\mathrm{V}$ súvislosti s vybudovaným prostredím ako priestorovo ukotvenou a teda neprenosnou komoditou, Harvey (1985) poukazuje na niekol'ko špecifik, ktorých dôsledkom je, že cirkulácia kapitálu fyzickým prostredím dynamicky kolíše, pričom v jednotlivých bodoch cirkulácie je vybudované prostredie vyradené, opustené, zničené a selektívne rekonštruované. Investovaním do nehnutel'ností vzniká zvláštny druh komodít so špecifickými vlastnost’ami. Tieto sú v spojení s jedinečnou polohou vzácne, kapitálové investície sú v nehnutel’nostiach dlhodobo viazané (imobilizované), pričom pomerne dlhý čas obratu vytvára bariéry d’alšej akumulácii, nehnutel’nosti sú tiež t’ažko likvidné a citlivé na zastarávanie (Harvey 1989b).

\footnotetext{
${ }^{1} \mathrm{Na}$ iných miestach hovorí o bezprostrednom význame „priestorového riešenia“ (spatial fix), ktoré predstavuje časovo obmedzenú sanáciu inherentných kontradikcií kapitalistického systému. Je artikulované v rôznych mierkach, od globálnej po lokálnu, kde je jeho materiálnym vyjadrením mestské vybudované prostredie.
} 
Schopnost' vybudovaného prostredia prinášat' výnosy závisí hlavne od kolísania hodnôt dvoch rozdielnych elementov. Jedným je poloha v priestore, druhým je vlastná vybudovaná štruktúra a jej zdokonal'ovanie. Polohová renta je kontextovo závislá veličina, ktorej hodnota môže rást' alebo klesat' v súvislosti s externalitami spôsobenými lokalizáciou iných prvkov prostredia. Záujem o konkrétnu polohu a teda $\mathrm{s}$ ním spojená výška potenciálnej renty súvisí s prítomnostou či absenciou rôznych javov zvyšujúcich kvalitu prostredia. Poloha v rámci metropolitnej oblasti, resp. voči centru a hlavným dopravným tepnám, ako i charakteristiky konkrétnej štvrte (vybavenie technickou infraštruktúrou, prehustenost' zástavby, obmedzená priepustnost' dopravy, dostatok zelene či zaujímavé výhl'ady a pod.) predstavujú príklady vyjadrení priestorových vzt'ahov, ktoré môžu ovplyvnit' výšku výnosov lokalizovaných nehnutel'ností. Ich hodnota sa tak stáva „rukojemníkom rozmarov blízkosti a jej vzt'ahu k d'alším vlastnostiam“" (Weber 2002, p. 521). Na druhej strane, vlastné vybudované prostredie dňom dobudovania začína hodnotu strácat' tak v dôsledku fyzického opotrebenia, ako aj morálneho zastarania, ktoré sa podpisujú pod znižovanie úžitkových hodnôt budov. Proces poklesu hodnoty môže byt spomalený vedomými rozhodnutiami investovat'. Takáto revalorizácia sa môže uskutočnit' prostredníctvom opráv, inovácií konštrukčných materiálov, dizajnu či vybavenosti a pod., čím sa zabezpečí pretrvávanie úžitkových hodnôt (Weber 2002).

V prípade, že o nehnutel'nost' v danej lokalite za existujúcich podmienok na trhu prestane byt' záujem, táto stráca schopnost' prit'ahovat' cirkulujúci kapitál a sama tak stráca hodnotu i cenu. Devalorizácia pokračuje do momentu, ked' rozdiel medzi realizovanými (kapitalizovanou pozemkovou rentou) a potenciálnymi výnosmi, alebo „rent gap“ (Smith 1996), začne predstavovat' dostatočne vel'ký stimul pre nové kolo investovania $\mathrm{v}$ lokalite. Vybudované prostredie je tak podriadené kreatívnej deštrukcii podl'a rytmov kapitalistickej ekonomiky, ked', či už na globálnej alebo lokálnej úrovni, obdobia stavebného rozmachu striedajú časy úpadku a deštrukcie (Smith 2000).

Doposial' načrtnutá perspektíva zatial' nezohl'adňuje mnohé mimoekonomické pôsobenia, ktoré v praxi môžu ovplyvnit' osudy vybudovaných štruktúr. Proces kreatívnej deštrukcie vybudovaného prostredia však nemôže byt' vnímaný ako prísne determinovaný trhovými silami. V praxi "extrakciu" hodnoty miesta na rôznych úrovniach ovplyvňuje pôsobenie širokého spektra štátnych a neštátnych (netrhových) aktérov (Weber 2002). Ich pôsobením môže napríklad dochádzat' $\mathrm{k}$ rôznym definíciám mimoekonomických úžitkov existujúcich prvkov vybudovaného prostredia, ktorých prípadná preferencia smeruje k podpore ich zachovania. Ekonomické bremeno spojené s takýmto rozhodnutím potom musí byt' vynútené nejakou formou mimoekonomického tlaku, v prípade priznania kultúrnych hodnôt budove ide spravidla o mechanizmy inštitucionálnej pamiatkovej ochrany. V praxi môže výsledok vzt'ahov medzi kultúrou a ekonomikou nadobúdat' široké spektrum konkrétnych podôb, od úplného prekrytia po neprekonatel'ný rozpor. Splynutím symbolickej (resp. neekonomicky definovanej úžitkovej hodnoty) a ekonomickej hodnoty je stav, ked' sa kultúra stane súčast'ou produkcie a spotreby spojenej s akumuláciou kapitálu, teda, ked’ sa kultúra komoditizuje (Kong 1997, p. 100, pozri tiež Mitchell a Waal 2009). Na opačnom póle stojí zásadný rozpor, ktorý musí byt' riešený v prospech jednej alebo druhej hodnotovej perspektívy so všetkými dôsledkami. V takomto prípade ide o politickú otázku definície verejného záujmu, pri ktorej riešení má nezastupitel’nú úlohu štát a jeho inštitúcie. 
V súvislosti so štátom, mimoekonomickými funkciami, hodnotami a mimoekonomickými donútením ešte treba spomenút' skutočnost', že štát okrem toho, že je dôležitým aktérom pri nastavovaní parametrov regulačného prostredia (napr. mierou preferencie ekonomických a kultúrnych hodnotových perspektív), je sám budovatel'om a využívatel'om mestského hmotného prostredia. Miera jeho kapacít intervenovat' sa pritom môže v čase i priestore menit'. Pri periodizácii industrializácie, resp. urbanizácie úzko súvisiacej s industrializáciou, autori a autorky rozlišujú viacero etáp na základe meniacich sa podmienok určujúcich ich základné parametre. $\mathrm{V}$ tomto kontexte je možné oddelit' 1) obdobie počiatkov a postupného rozvoja modernej priemyselnej výroby a s ňou spojenej urbanizácie na území dnešnej Bratislavy, 2) obdobie štátneho socializmu so špecifickými politickými a ekonomickými podmienkami určujúcimi charakter industrializácie a urbanizácie a 3) obdobie postsocialistickej transformácie, opät' charakteristické zásadnou rekonfiguráciou základných vzt’ahov produkujúcich a transformujúcich mestský priestor. Hoci viacerí autori rozlišujú $\mathrm{v}$ rámci predvojnového obdobia rozvoja priemyslu a miest u nás obdobie do prvej svetovej vojny a medzivojnové obdobie prvej CSR (Mládek 1990 a Korec 2013), v predloženom príspevku bude obdobie do konca druhej svetovej vojny, resp. nástupu obdobia štátneho socializmu chápané ako obdobie kontinuity rozvoja priemyslu v podmienkach kapitalizmu, ktoré umožnilo vznik objektov a štruktúr dnes označovaných ako historický industriál (Sabol 2011).

V súvislosti s intervenciami a regulačnými kapacitami verejnej sféry, resp. štátu, a tiež vzhl'adom na predstavený rámec sa treba ešte vysporiadat' so socialistickou etapou industrializácie a urbanizácie, ktorá na prvý pohl’ad nezapadá do diskusie o vzt’ahu kapitalizmu a urbanizácie, no tiež predstavuje zásadný moment pre historický pohl'ad na urbanistický vývoj Bratislavy v tomto príspevku. Na túto etapu je možné nazerat' $z$ viacerých perspektív, kde na jednej strane stoja názory, že systémy oddelené železnou oponou stoja na odlišných fundamentoch, na druhej zdôraznenia spoločnej ukotvenosti $\mathrm{v}$ univerzálnom modernizačnom procese, resp. jeho európskym vyjadrením. Asi nemá zmysel spochybňovat' tvrdenie, že mnohé nastavania vzd'al'ovali reálne existujúci socializmus od abstrakcie ideálne fungujúceho kapitalizmu, ktorá stojí v jadre predstavenej teórie transformácie vybudovaného prostredia. Existencia politicko-ekonomických špecifík usporiadania obdobia socializmu, najmä výraznejšia moc štátu vyjadrená okrem iného kontrolou výrobných prostriedkov, kontrolou mestskej pôdy, pozemkov a nehnutel'ností spoluutvárali produkciu do istej miery špecifického vzorca materiálnej mestskej krajiny (Sýkora 2009). Predložený text si nekladie za svoj ciel' zodpovedat' otázku chápania odlišností priestorového usporiadania medzi kapitalistickými a socialistickými mestami. Skôr si, okrem analýzy úloh kapitálu v produkcii mesta, všíma aj intervencie verejnej sféry, ktorá sa odrazila v osudoch historických priemyselných štvrtí $\mathrm{v}$ Bratislave. A hoci tieto mohli byt' intenzívnejšie a ich paleta pestrejšia práve v období štátneho socializmu, mimoekonomická intervencia vo svojich rôznych formách nie je výlučným atribútom iba tejto epochy.

Na základe uvedeného je možné sformulovat' základný ciel' predloženého príspevku ako analýzu vývoja a transformácie historickej industriálnej vrstvy. Pod historickou industriálnou vrstvou budú chápané prvky vybudovaného prostredia, ktoré v čase svojho vzniku (teda od počiatkov priemyselnej revolúcie v meste do druhej svetovej vojny, resp. rozsiahlejšej povojnovej obnovy, ktorá sa už spája s režimom štátneho socializmu) plnili priamo výrobnú funkciu, prípadne funkcie s výrobou úzko spojené (skladovanie, nákladná doprava a pod.). Vznik a d'alšie 
osudy takto definovanej časti materiálneho prostredia mesta budú skúmané prostredníctvom kolísania hodnôt lokalít a vlastných vybudovaných štruktúr spôsobených politickými, ekonomickými, sociálnymi či kultúrnymi zmenami, či urbanistickou transformáciou mesta samotného. V rámci plnenia takto stanoveného ciel'a budem hl'adat' odpovede na otázky, ako sa menila relatívna poloha priemyselných štvrtí, resp. ako sa menili charakteristiky ich bezprostredného okolia i atribúty d'alších relevantných priestorových vzt'ahov ovplyvňujúcich potenciálnu polohovú rentu. V kontexte meniacich sa atribútov polohy, no tiež zmien parametrov miestnej ekonomickej bázy a z nich plynúcich nárokov na využívanie mestského priestoru budú potom d'alej skúmané, ako sa menili úžitkové hodnoty vybudovaného prostredia. Zvláštnu pozornost' venujem formám mimoekonomických intervencií podporujúcich vznik, ochranu, prípadne ohrozenie a zánik historických štruktúr v podmienkach rôznych dejinných období.

\section{URBANISTICKÝ VÝVOJ V OBDOBÍ ROZVOJA KAPITALISTICKEJ PRIEMYSELNEJ VÝROBY}

Mesto, v súčasnosti nazývané Bratislava, zažilo obdobia významného rozvoja spojeného s lokalizáciou mimoekonomických aktivít. Tieto dosiahli historicky najväčší význam počas troch storočí, ked' slúžilo ako korunovačné mesto uhorských král'ov (a ich sídlo, snemovné mesto král'ovstva, sídlo arcibiskupa a najdôležitejších inštitúcií krajiny). Avšak klúčovým pre moderný urbanistický vývoj bol rozmach priemyslu. Od druhej polovice 80. rokov 19. storočia, teda takmer presne 100 rokov po tom, ako Prešporok prestal byt' hlavým mestom Uhorska, začína jeho provinčnú trajektóriu vychyl'ovat' moderná industrializácia a továrenská vel'kovýroba.

Mesto bolo významným centrom remesiel a počiatkov rozvoja kapitalistickej manufaktúrnej výroby v Uhorsku už v 18. storočí (Kohútová a Vozár 2006), v porovnaní s rakúskou čast'ou monarchie či vyspelými krajinami západného sveta však zaostávalo. Rozdielna dynamika rozvoja priemyslu v Uhorsku a západnej Európe (pozri napr. Hapák 1972) mala viaceré príčiny. Medzi najčastejšie uvádzané historické bariéry rozvoja továrenskej vel'kovýroby v Uhorsku patria viaceré parametre sociálnych vzt’ahov (napr. rozdiely v dedičnom práve medzi rakúskou a uhorskou čast'ou monarchie), ktoré menšou mierou stimulovali rast miest a na druhej strane konzervovali feudálne sociálne štruktúry. V Uhorsku predstavovali dôležitú udalost' na ceste od feudalizmu ku kapitalizmu následky revolučného roku 1848, ktoré napriek mnohým kompromisným riešeniam priniesli viaceré reformy. Zrušenie poddanstva $^{2}$ znamenalo uvol'nenie množstva pracovných síl na pomerne prel'udnenom vidieku, ktoré mali podporit' rozvoj manufaktúr a neskôr strojovej továrenskej výroby v mestských centrách. V Prešporku už v 50. rokoch 19. storočia bolo možné sledovat' počiatky nastupujúceho trendu zakladania manufaktúr. Popri viacerých menších boli založené aj dva väčšie podniky reprezentované tabakovou továrňou (1853) a starou mestskou plynárňou (1855). Tieto predznamenávali zmeny, ktoré mali mocniet's blížiacim sa prelomom storočí. Napriek tomu, že v tabakovej továrni bolo zamestnaných vyše 500 osôb, prevažne žien, vo všeobecnosti stále dominovala malovýroba a len vel'mi obmedzené využívanie strojov (Bokes 1982).

\footnotetext{
${ }^{2}$ Okrem zrušenia poddanstva je za dôležité považované napr. zrušenie colnej hranice medzi rakúskou a uhorskou čast'ou monarchie z roku 1850, či uzákonenie slobody zakladania živností z roku 1860 (pozri Hallon 2013).
} 
Ďalší výrazný impulz pre rozvoj modernej priemyselnej výroby v Uhorsku prinieslo rakúsko-uhorské vyrovnanie z roku 1867, ktoré znamenalo presun viacerých kompetencií kl'účových pre stimulovanie nových ekonomických aktivít do Budapešti. Tri hospodárske ministerstvá a vlastný rozpočet sa stali bázou na prijímanie politík podpory rozvoja priemyslu a celkovej modernizácie krajiny. Dôležitú úlohu pri dobiehaní priemyselne vyspelejších oblastí Európy predstavovala séria legislatívnych opatrení, tzv. industrializačné zákony (1881, 1890 a 1907). Ich ciel'om, okrem všeobecnej podpory rozvoja moderného priemyslu a budovania infraštruktúry $\mathrm{v}$ Uhorsku, bolo tiež reagovat' na sériu medzinárodných hospodárskych kríz, ktoré od recesie roku 1869 a krachu viedenskej burzy roku 1873 cyklicky narúšali rozvojové trendy. Súčast'ou reforiem boli na jednej strane vol'notrhové „deregulačné“ opatrenia, na strane druhej rôzne podoby priamej a nepriamej štátnej intervencie. Využívané boli priame štátne dotácie, poskytovanie pozemkov, colných výhod a zliav, daňových prázdnin, dopravných zliav, bezúročných pôžičiek a pod. (Hallon 2013).

$\mathrm{V}$ rámci podporných politík idúcich nad rámec industrializačných zákonov bola popri d’alších prvkoch modernizovanej infraštruktúry (napr. telegraf) zvláštna pozornost' venovaná rozvoju železničnej dopravy. Počiatky podpory železníc siahajú ešte do predrevolučných čias, ked' plán výstavby železnice prijal Uhorský snem už v 30. rokoch 19 . storočia. $\mathrm{V}$ ich realizácii sa postupne pokračovalo po revolúcii v rámci industrializačných zákonov (Hallon 2013). Prvá trat' pôvodne konskej železnice spájajúca Bratislavu a Trnavu bola vybudované v rokoch 1838 - 1843, prvá parná železnica Bratislava - Marchegg (1848) predstavovala základ v budúcnosti najfrekventovanejšej železničnej trate v Uhorsku, spájajúcej hlavné mesto Budapešt' s priemyselne vyspelými západnými čast'ami monarchie. Na túto v meste nadviazal ,vejár slovenských železníc do údolí Váhu, Nitry, Hronu a napokon železnica Žitného ostrova“ (Hromádka 1933, p. 7). Funkciu dopravného uzla navyše posilňoval Dunaj s nákladným prístavom, ktorého význam v súvislosti s rozvojom železníc d’alej rástol ${ }^{3}$. Historická Železničná stanica Bratislava-Nové Mesto (neskôr ŽS Bratislava-Nivy), na parnú prevádzku prebudovaná začiatkom 80. rokov, sa stala kl'účovým prvkom dopravnej infraštruktúry, kde sa po dobudovaní mosta cez Dunaj (1891) zbiehali železničné trate z oboch brehov i ned'alekého prístavu, a okolo ktorej vznikla najvýznamnejšia priemyselná zóna v meste.

Okrem polohy vo vzt’ahu $\mathrm{k}$ dopravným líniám prispel $\mathrm{k}$ lokalizácii výroby do vtedajšieho Prešporka d’alší špecifický politicko-geografický faktor, konkrétne hranica medzi dvoma čast’ami monarchie. Vd'aka rozhodnutiu vlády v Uhorsku z roku 1890 o povinnosti uprednostňovat' domácich výrobcov pri štátnych zákazkách došlo $\mathrm{k}$ vybudovaniu viacerých filiálok viedenských podnikov (napr. Kablo). Ako však upozorňujú niektorí autori, mnohé boli zriadené iba účelovo na obchádzanie tohto nariadenia - v novozaložených pobočkách na území mesta sa robili iba finálne operácie (Jarošek 1985). Na obdobnú geografickú súvislost' lákajúcu zakladat' priemyselné podniky práve v Prešporku upozorňuje na príklade podniku DynamitNobel historik Holec (2011). Ten zdôrazňuje hraničnú polohu, ktorá umožnila „kalku-lovat’ s rôznymi strategicko-taktickými alternatívami. Vedenie podniku síce

\footnotetext{
${ }^{3}$ Ročný objem prekladu v bratislavskom prístave narástol len medzi rokmi 1913 a 1939 zo 41370 na 1012004 ton (Hromádka 1943). Prístavu sa začalo zvlášt' darit' po tom, ako Bratislava prestala byt' len priemyselným, no predsa len provinčným mestom na Dunaji medzi dvoma hlavnými mestami monarchie, ale sama získala na politickom a správnom význame.
} 
pochádzalo z Rakúska a podnik spadal pod viedenskú centrálu, ležal však na území Uhorska, a to mu umožňovalo deklarovat' ho rôznym spôsobom a kedykol'vek v budúcnosti t'ažit' z výhod poskytovaných jednou i druhou čast'ou štátu“ (Holec 2011, p. 12).

Proces koncentrácie kapitálu a rozvoj nových technológií vytvárali predpoklady pre rast významu priemyselnej vel'kovýroby. Vznikajúce podniky predstavovali najčastejšie akciové spoločnosti so zahraničnou účast'ou, pričom sa výroba nezriedka orientovala na medzinárodné trhy (napríklad Dynamit-Nobel či Kablo). Prílev koncentrovaného kapitálu, technologický pokrok a ich zhmotnenie v modernom továrenskom priemysle znamenali definitívny koniec starších podôb výroby a priniesli nový impulz pre lokalizáciu nových podnikov, ako aj celkový urbanistický vývoj. Najstaršia mimomestská zóna výroby naviazanej na zdroj vodnej energie vyrástla v Mlynskej doline ${ }^{4}$, zatial' čo remeselné dielne a menšie manufaktúry fungovali v rámci intravilánu. S rastom významu parného stroja dochádza k postupnej zmene dôležitosti lokalizačných činitel'ov a formovanie nových zón ${ }^{5}$ na periférii vtedajšieho mesta. Obuchová et al. (1985) identifikovali tri hlavné historické priemyselné oblasti (obr. 1). Prvou bola najvýznamnejšia industriálna zóna vymedzená ulicami Martanovičova (dnes Pribinova), Dostojevského rad, Košická a Mlynské nivy. K nej prilieha oblast' Mlynské nivy a Trnavská cesta. Ned'aleko od nich sa nachádza územie nadväzujúce na centrum ulicami Radlinského a Steinerova (dnes Krížna). Mimo tohto hlavného t’ažiska priemyselnej výroby fungovalo niekol'ko d'alších tovární roztrúsených po meste i za jeho hranicami, ako napr. Matador a smaltovňa v Petržalke, modernizované výroby v Mlynskej doline a továrne za mestom t’ahajúce sa popri železničnej trati, z ktorých od mesta najvzdialenejšou bola z povahy produkcie lokalizovaná továreň Dynamit-Nobel. Obuchová a Majerová, autorky mapovej prílohy k Zborníku MSPSOP v Bratislave, č. 8: Technické pamiatky Bratislavy (Schwarzová et al. 1985), identifikovali 24 tovární a technických diel v prvej spomenutej zóne, kde k najvýznamnejším prevádzkam patrili Kablo, rafinéria Apollo či Klingerova továreň. V druhej len tri, zato vel'kost'ou významné prevádzky (Cvernovka, Danubius a Mestský bitúnok na Miletičovej) a v tretej zóne 10 tovární a technických pamiatok. Spolu teda 37 tovární na bezprostrednej hranici vtedajšieho mesta ${ }^{6}$.

Zatial' čo prvá zóna alebo „továrenská štvrt““ (Hromádka 1933) si svoj výlučne industriálny charakter udržala až donedávna, ostatné uvedené predstavovali už v 30. rokoch zmiešané územia, kde popri závodoch vznikali rôzne obytné súbory. Počiatky výstavby industriálnych areálov však využivali vol’né či málo zastavané územia na hraniciach vtedajšieho mesta, alebo ešte vzdialenejšie lokality (obr. 1).

\footnotetext{
${ }^{4}$ Prvé mlyny tu vznikli už v 13. storočí, v 14. vieme o deviatich obilných mlynoch, ktoré dali doline nové meno už v 15. storočí (Mühltal). V prevádzke boli do polovice 19. storočia, dva boli zmodernizované a slúžili d'alších 20 rokov (Hanušin 1985).

${ }^{5}$ V oblasti Mlynskej doliny v prevádzke ostali Rothova Patrónka a Kühmayerov závod na výrobu šnúr a doplnkov, ktoré však prijali nové technológie parného stroja.

${ }^{6}$ Odvetvová štruktúra rozvíjajúceho sa priemyslu bola pomerne rôznorodá. Zastúpené tradičné odvetvia, ako potravinársky (Stein, Manderla a Stollwerck), textilný (Helleho továreň, Kühmayerova, Regenhardtova súkenka, Todesko a spol., Klingerka, Cvernovka a Danubius) a stavebný priemysel (Durvayova tehelňa, Stanz a Meld a Menzlova továreň), rovnako však vysoko moderné odvetvia II. priemyselnej revolúcie - chemický (DynamitNobel a Apollo), strojársky (Werdorferova továreň), elektrotechnický (Siemens-Schuckert a Kablo) či moderný zbrojársky (Rothova továreň) priemysel (Obuchová 1985).
} 


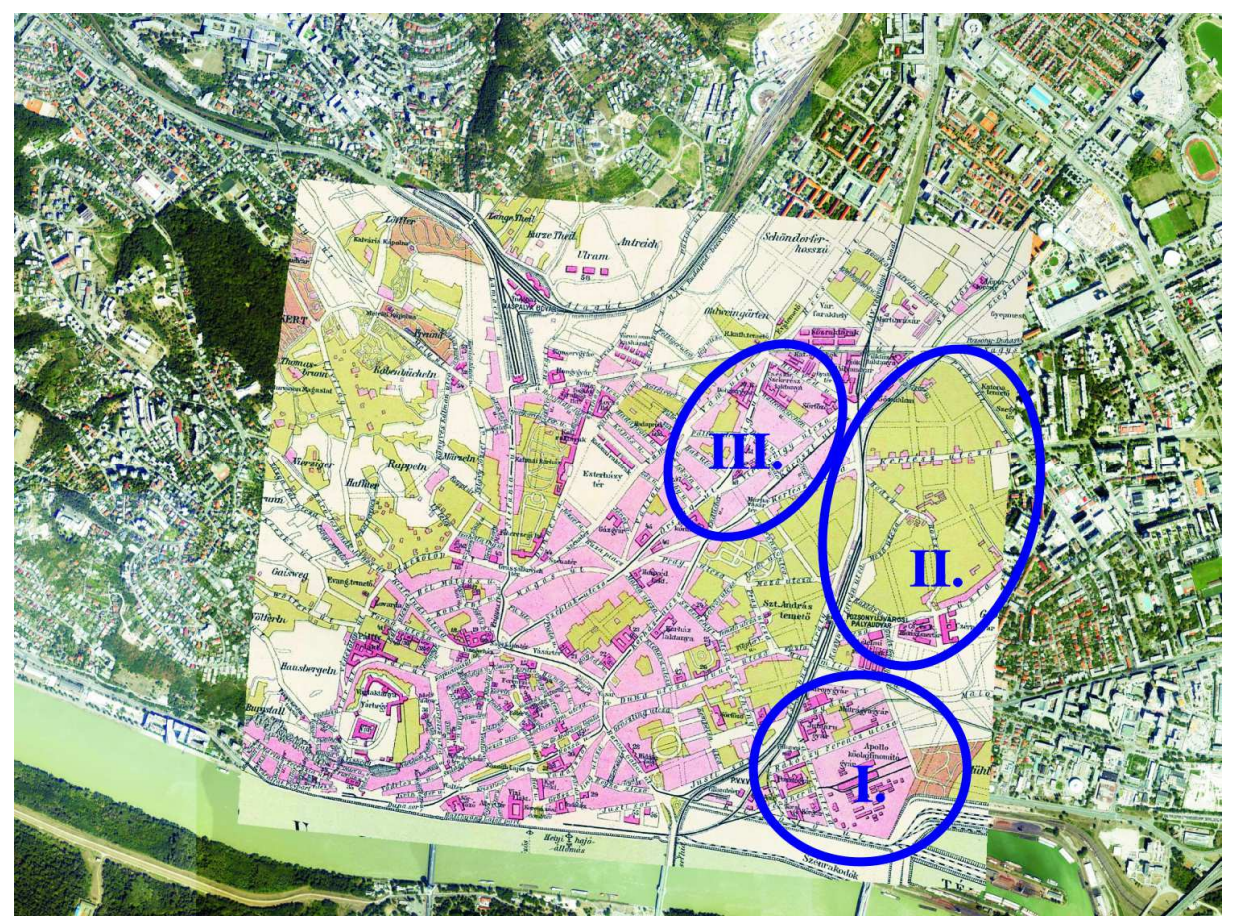

Obr. 1. Meniaca sa relatívna poloha hlavných industriálnych zón (1910 - súčasnost')

Výrez z historickej mapy zachytáva svojho času periférnu polohu priemyselných zón, ktoré sa v minulosti nachádzali na okraji intravilánu, či za hranicou kompaktného mesta. Za sto rokov urbanistického rozvoja sa však tieto stali súčast’ou širšieho centra. I, II a III - priemyselné zóny podl’a Obuchovej (1985). Mapové zdroje: Google maps, Pozsony - szabad királyi város (1910).

Periférnost' prostredia, v ktorom vznikali nové priemyselné zóny, zachytávajú viacerí autori ${ }^{7}$, pričom lokalizácia vlastných tovární, dopravnej infraštruktúry a rezidenčných ,kolónií “ postupne transformovala toto niekdajšie zázemie. O lokalite Mlynské nivy hovorí Fekete (1948) ako o území „,neúrodnej pôdy mŕtvych ramien Dunaja“. Postupne tu však vzniká najvýznamnejšia továrenská zóna v meste. Zóna v okolí Radlinského ulice vyrástla v pôvodnej predmestskej osade Blumentál. Tabaková továreň spolu s Grünbergerovým závodom na kefy vytvorili jadro priemyselnej štvrte, kde sa ,typická vinohradnícka zástavba predmestia pomaly menila na štvrt' nájomných domov v dotyku výrobných zariadení“ (Gojdič a Zvedelová 2006). Od mesta najvzdialenejší podnik Dynamit-Nobel „bol lokalizovaný do močaristého priestoru medzi Bratislavou a dedinou Rača. Pravda, v tom čase nikto netušil, že o polstoročie vývoj mestskej aglomerácie Dynamitku úplne pohltí a že o sto rokov sa rozvoj podniku bude odohrávat' uprostred obytných častí" (Holec 2011, p. 12). Bartošová (2018) ukazuje návrhy medzinárodnej sút'aže plánov urbanistického rozvoja z roku 1929, ktoré aj do plánovanej budúcnosti uvažovali o polohe najvýznamnejších priemyselných zón (najmä zóna 1 a továreň DynamitNobel) ako o okrajových.

\footnotetext{
${ }^{7}$ Pre porovnanie, predindustriálny obraz mestskej krajiny a charakteristík okolia z konca 18. storočia na základe analýzy Korabinského mapy analyzuje Hrnčiarová (2016).
} 
Spolu s rozvojom továrenskej vel'kovýroby rastie počet obyvatel'ov a budujú sa nové obytné štvrte. Mesto populačne narástlo zo 42-tisíc obyvatel'ov v roku 1850 na 62-tisíc v roku 1900 a v roku 1921 tu žilo už 93-tisíc obyvatel’ov. Do prvej svetovej vojny sa stavali nové obytné bloky na Palisádach, v okolí dnešnej Stefánikovej na východe a juhovýchode po Ondrejský cintorín a Lazaretskú (Johanidesová 1982), po vojne sa mesto d'alej rozširuje a zahust'uje sa výstavba najmä v pril'ahlých častiach Nového Mesta a Ružinova ${ }^{8}$ (Hromádka 1933 a Halás a Džupinová 2007). Svoje vlastné kolónie si budovali aj viaceré fabriky, napríklad Grünbergerov kefársky závod (neskôr budova štátnej poist’ovne na Radlinského ulici), Klingerova továreň, Danubius a d'alšie. Realizujú sa viaceré zaujímavé projekty nachádzajúce oporu v progresívnych legislatívnych úpravách (Osyková 2015), často za účasti uznávaných architektov. Celkovo sa len v medzivojnovom období postavilo vyše 25000 bytov (Beňuška 1982).

Industrializáciou sa urbanizujú i viaceré prímestské obce, ako prvá a najvýznamnejšia Petržalka ${ }^{9}$ s vlastnou priemyselnou štvrt'ou, no postupne pribúdajú d'alšie (Bartošová a Haberlandová 2016). Osady v bezprostrednom zázemí alebo „obce banlieue“ (Hromádka 1935) dostávajú doposial' nepoznaný rozvojový impulz. „V každej osade vidiet' dva sídelné typy: starú rol'nícku dedinu a kolónie nových prist’ahovalcov nerol'níckeho zamestnania“" (Hromádka 1935, p. 208). Zatial' čo v obciach Petržalka, Prievoz a Rača (Račišdorf) už dominujú kolónie s mestským obyvatel'stvom, vo Vajnoroch, Dúbravke či Biskupiciach je tento trend zatial' nevýrazný. Ukážkovým príkladom tohto procesu je nová kolónia $\mathrm{v}$ Račišdorfe vznikajúca medzi Dynamitkou a mestom, ktorá je ,úplne oddelená od starej radovej dediny rol’níkov“, no „rozložená pozdíž silnice“ a ,za dajaký čas spojí Račišdorf s Bratislavou“" (Hromádka 1935, p. 209).

Zatial' čo prvá svetová vojna znamenala pre niektoré podniky útlm výroby, viaceré odvetvia - chemický, strojársky či textilný priemysel, vyrábajúce na základe štátnych zákaziek pre armádu, zažili svoj dovtedajší vrchol zamestnanosti, produkcie i ziskov a ešte posilnili priemyselný význam mesta. Koniec vojny a vznik ČSR síce priniesli mnoho zmien, na druhej strane základné rámce fungovania kapitalistického hospodárstva zostali v platnosti. Príkladom nech je proces nostrifikácie, ktorý znamenal zmenu v „,národnostnej“ štruktúre kapitálu, nie jeho významu. Išlo o povojnové snahy o elimináciu kapitálu nedohodových mocností a teda vplyvu Viedne a Budapešti v nástupníckych štátoch. V ČSR bola prostriedkom hospodárskej emancipácie nového štátu, ktorému dávala väčšiu mieru kontroly a zabezpečovala, že vyprodukované zisky neodtečú za hranice. V porovnaní s minulost'ou tak popri rastúcom význame štátu, ktorý však načas zostal jedinou baštou hospodárskeho liberalizmu v stredoeurópskom priestore, rastie úloha domáceho a „dohodového“ kapitálu (Holec 2011).

Komplikovaná medzinárodná situácia, koniec vojnovej konjunktúry a d’alšie povojnové ekonomické otrasy, hospodárske problémy novoustanovenej republiky, strata vnútorných trhov monarchie, rast vplyvu významnej konkurencie priemyslu

\footnotetext{
${ }^{8}$ Zatial' čo vilové štvrte zámožnejších vrstiev vznikali najmä na svahoch severne od hradu, v štvrti „Hausberg“, štvrte rodinných domov stredných vrstiev obyvatel'stva sa budovali napr. vo „Westend“ na západnom, na Kolibe na severnom a v starom Ružinove na východnom okraji mesta. Ešte d'alej od mesta vznikli robotnícke štvrte Trnávka a Slovany, či viacero núdzových kolónií ako Pálenisko na juhovýchode, Starý háj na pravom brehu Dunaja i menšie skupiny domov na Machnáči a pod Kolibou (Halás a Džupinová 2007).

${ }^{9}$ V Petržalke narástol počet obyvatel'ov medzi sčítaniami 1921 a 1930 o 231,53 \%, čím sa po Zlíne zaradila na druhé najdynamickejšie rastúce sídlo v ČSR, Prievoz so 193,18 \% bol piaty (Hromádka 1933).
} 
z Česka ${ }^{10}$ a mnohé d'alšie skutočnosti znamenali dočasný pokles produkcie a postupnú zmenu štruktúry priemyslu. Na druhej strane, rast politickej a hospodárskej významnosti mesta $\mathrm{v}$ rámci CSR priniesol mnoho impulzov rozvoja a dvadsiate roky 20. storočia zaznamenali doposial' najväčší absolútny i relatívny rast počtu obyvatel'ov. V roku 1930 populácia mesta dosiahla vel'kost' 124 tisíc, čo predstavovalo vyše $30 \%$ nárast počas jednej dekády ${ }^{11}$. Popri rozvoji mimoekonomických funkcií zostáva pre mesto kl'účové hospodárstvo a úloha priemyslu, ktoré sa navzájom podporovali. Bratislava predstavovala ,,akúsi hospodársku enklávu Slovenska“ (Provazník 1982, p. 219), najvýznamnejšie obchodné a priemyselné centrum Slovenska a výhodný oporný bod ,„pre ovládnutie hospodárskeho života na celom Slovensku“" (p. 221).

Prvá polovica 20. storočia so sebou priniesla d'alšie historické udalosti, ktoré síce ovplyvňovali ekonomický život v meste, no nemenili základné nastavenie kapitalistických výrobných vzt’ahov. Významnejšie rozkolísania vývojovej dynamiky priniesla hospodárska kríza v roku 1929 znamenajúca pokles výroby a útlm investičnej činnosti. Neskôr udalosti rozpadu ČSR a druhá svetová vojna priniesli d'alšiu zmenu štruktúry kapitálu, tentoraz v prospech ríšskeho (Hallon 2010). Vojnové úsilie stimulovalo priemyselnú výrobu, na druhej strane s blížiacim sa koncom vojny pribúdali škody spôsobené bombardovaním, ktoré znamenali prakticky definitívny koniec rafinérie Apollo, takmer celý vyhorel závod Siemens a poškodené boli aj d’alšie továrne. Ustupujúca nemecká armáda strhla most cez Dunaj a k viacerým škodám došlo v súvislosti s bojmi v meste. Popri odstraňovaní škôd sa v októbri 1945 začína proces znárodňovania, ktorý sa v prvom kole týkal 156 z 286 dôležitých závodov (Pleva 1982, p. 296). Úplne zavíšený bol tento proces po roku 1948.

\section{OBDOBIE ŠTÁTNEHO SOCIALIZMU}

Znárodnenie priemyslu však znamenalo len čast' komplexnej transformácie vzt’ahov produkujúcich mestskú krajinu. Všeobecné podmienky koncentrácie politických, ekonomických, rozhodovacích a výkonných kapacít centralizovaného plánovaného hospodárstva prispeli $\mathrm{k}$ tomu, že mesto v nových podmienkach dynamicky rástlo a tento rast sa často realizoval prostredníctvom pomerne odvážnych projektov. Jedným z výsledkov rastu bola skutočnost', že tradičné priemyselné zóny zásadne zmenili svoju relatívnu polohu. Posilňovanie nepriemyselných a mimoekonomických funkcií mesta a zmeny v štruktúre miestnej ekonomiky zase znamenali pokles významu priemyslu. Navyše, prvýkrát sa začali historické industriálne štruktúry vnímat' cez prizmu pamiatkových hodnôt.

Obdobie štátneho socializmu prinieslo d'alšie zintenzívnenie procesu urbanizácie. Len „V priebehu 30 rokov (1950 až 1980) sa zdvojnásobil podiel mestského obyvatel'stva“" (Mládek 1990, p. 68). Od sčítania z roku 1940, teda pred pričlenením Prievozu, Petržalky, Karlovej Vsi, Dúbravky, Lamača, Devína, Rače a Vajnor, populácia mesta narástla dokonca zo 139 na 380-tisíc v roku 1980 a na zatial' rekordných 442-tisíc obyvatel'ov v roku 1991, teda trojnásobne. Povojnová výstavba prebiehala najskôr $\mathrm{v}$ hraniciach vnútorného mesta, kde sa $\mathrm{v}$ prvej fáze realizoval projekt prestavby starých štvrtí, ktorý bol spojený s vel’kými asanáciami (Korec

\footnotetext{
${ }^{10}$ Česko zdedilo až 80 \% priemyselných kapacít rakúskej časti monarchie (Hallon 2010).

${ }^{11}$ Aj v roku 1930 však bola Bratislava až štvrtým najväčším mestom v ČSR po Prahe, Brne a Ostrave, hoci sa práve dostala pred Plzeň.
} 
a Smatanová 2000) a následným budovaním sídlisk skompaktňujúcich mestskú štruktúru. Po vyčerpaní rezerv sa pristúpilo k realizácii ambicióznych projektov komplexnej bytovej výstavby $\mathrm{v}$ podobe budovania panelových sídlisk, postupne čoraz vzdialenejších od mesta ${ }^{12}$ (Halás a Džupinová 2007 a Moravčíková et al. 2011). Intenzívna bytová výstavba mala za následok, že v roku 1980 bolo 77 \% bytového fondu mesta vybudovaného po roku 1945 (Očovský 1989) a koncom 80. rokov žilo v bytoch $\mathrm{v}$ panelových domoch až 80 \% Bratislavčanov a Bratislavčaniek. Takáto intenzita budovania mesta mala nevyhnutne za následok skutočnost', že pôvodne periférne ležiace priemyselné zóny sa na viacerých miestach dostali do kolízie s trajektóriami urbanistického rozvoja.

Postupne dochádzalo k oslabovaniu vzt'ahov podporujúcich industriálny charakter lokalít. Hoci výroba v existujúcich závodoch bola počas socializmu zväčša zachovaná, tieto narušenia sa mali prejavit' neskôr. So silným postavením mestského plánovania a koncentráciou politických a ekonomických kapacít umožňujúcich realizáciu plánovaného mestského rozvoja bolo možné uskutočnit' viaceré rozsahom i formou bezprecedentné projekty. V tomto období sa historicky najvýznamnejšie materializovala monumentalita $\mathrm{v}$ architektúre spojená $\mathrm{s}$ reprezentáciou - či už štátnej moci, národnej mytológie, historickým pripomínaním alebo demonštráciou ekonomickej vitality (Moravčíková 2009). Táto významným spôsobom premenila (hoci nie výlučne) územie rozrastajúceho sa centra, teda aj oblasti, kde sa v minulosti sformovali priemyselné zóny. Príkladom je os Mýtna a Radlinského, kde areál starej mestskej plynárne (1856 - 1935) musel ustúpit’ realizácii adaptácie projektu „vládnej štvrte“, ktorého pôvodný koncept vzišiel zo sút’aže v roku $1942^{13}$. Aj v iných prípadoch sa realizovali plány z minulosti. Príkladom je selektívna aplikácia zásad rozvoja mesta, ktoré vzišli z medzinárodnej sút’aže na generálny regulačný plán a železničné riešenie Bratislavy z roku 1929. Navrhované riešenia mali odstránit' bariéry urbanistického rozvoja mesta, a nie nevyhnutne sledovali ciel' podporovat' rozvoj priemyselnej výroby v pôvodných industriálnych zónach. Takými bol projekt preloženia železničnej stanice Bratislava-Nové Mesto či lokalizácia nových priemyselných areálov na juhovýchod od mesta (Beňuška 1982). Preloženie železničnej stanice a s ňou spojených významných líniových bariér v podobe úrovňového riešenia tratí prichádzajúcich z Petržalky i zo severu a budovanie železničného „obchvatu“ poza rozvojové rezidenčné lokality Ružinova priniesli od začiatku prác $\mathrm{v}$ 60. rokoch postupný pokles intenzity využívania až po úplné zastavenie dopravy v roku 1983. Následné odstránenie kol'ají a staničnej budovy urobilo bodku za infraštruktúrou, ktorá podporovala najvýznamnejšiu historickú priemyselnú zónu v meste a vyvíjala sa spolu s n̆ou.

Hoci úloha priemyslu ako faktora urbanizácie bola v Bratislave v porovnaní s väčšinou regiónov Slovenska nižšia (Mládek 1986), tento neprestal hrat' úlohu v mestskom rozvoji. Na dôležitosti však d’alej získavajú služby a funkcie spojené s administratívnym, politickým a kultúrnym významom, ktoré formujú urbanistický vývoj. Po druhej svetovej vojne boli v zásade všetky existujúce priemyselné areály zrekonštruované a revalorizované, navyše v období socialistickej industriali-

\footnotetext{
${ }^{12}$ Priestorový rast mesta reflektovali zmeny administratívnych hraníc, ked' v roku 1946 boli k Bratislave pričlenené dovtedy vidiecke obce Devín, Dúbravka, Karlova Ves, Lamač, Petržalka, Prievoz, Rača a Vajnory, v roku 1972, reșp. 1973 pribudli Devínska Nová Ves, Záhorská Bystrica, Podunajské Biskupice, Vrakuňa, Jarovce, Rusovce a Cunovo.

${ }^{13}$ Vzdialenejšie prevádzky ako tabaková továreň a továreň na kefy pretrvali, hoci s novým výrobným programom.
} 
zácie bolo v Bratislave postavených 31 nových závodov (Korec 2013, p. 124) a spolu sa hrubá priemyselná výroba medzi rokmi 1945 a 1985 zvýšila o 984,5 \%. Tieto nové investície sa už však často realizovali na novodefinovanej periférii rýchlo rastúceho mesta ${ }^{14}$, teda d'aleko od pôvodných industriálnych zón, ktorých poloha sa, naopak, stávala čoraz centrálnejšou ${ }^{15}$ (obr. 1). Do nových vzt'ahov sa však postupne dostávali aj jednotlivé budovy.

„Druhá polovica 20. storočia prenikavo degradovala vzt’ah $\mathrm{k}$ starým historickým industriálnym objektom: z hl'adiska potrieb výroby už nevyhovovali, uprednostňovala sa nová výstavba a nové technológie, alebo sa stavby znehodnocovali účelovými prístavbami a prestavbami“" (Šulcová 2009, p. 340). V takomto hodnotení obdobia štátneho socializmu však absentujú dve dôležité skutočnosti vplývajúce na d’alšie perspektívy prípadnej prezervácie industriálnej architektúry. Zachovanie aktívnej výroby a ňou determinovaných úžitkových hodnôt si na jednej strane často vyžiadalo adaptáciu budov či celých areálov na meniace sa technologicko-výrobné nároky a táto adaptácia tak priniesla deštrukciu viacerých potenciálnych kultúrnych hodnôt. Na strane druhej, v mnohých prevádzkach takto pretrvali viaceré historické budovy, na rozdiel od viacerých kapitalistických krajín, kde dochádza k zmene štruktúry miestnych ekonomík už od 60 . rokov 20 . storočia. Tu priemyselné areály, ktoré stratili schopnost' prit’ahovat' obiehajúci kapitál, ostali nevyužité a začali chátrat', prípadne sa dostali pod revitalizačné tlaky spojené s potrebou budovania novej mestskej krajiny zodpovedajúcej aktuálnym podmienkam. Ďalšou skutočnost'ou je, že práve v tomto období dochádza vôbec prvýkrát k uvedomeniu si novej formy mimoekonomických hodnôt spojených s vybudovaným prostredím, ku ktorému dochádza v kontexte rastu záujmu o historický industriál na medzinárodnej úrovni. Prvé kroky v mapovaní technických pamiatok na našom území spadajú do 50. rokov minulého storočia, no systematickejšie snahy prebiehajú v 70 . a najmä 80. rokoch. Prvý stavebno-historický výskum tovární na území Bratislavy sa realizoval v polovici 70. rokov na pôde Mestskej správy pamiatkovej starostlivosti (MSPS), neskôr v rámci Mestskej správy pamiatkovej starostlivosti a ochrany prírody $v$ Bratislave (MSPSOP). Spolupráca $s$ d'alšími inštitúciami ${ }^{16}$ vyvrcholila v roku 1983 sympóziom o technických pamiatkach Bratislavy, vydaním už spomínaného zborníka v roku 1985 a zápisom 13 (z 18 navrhovaných) technických pamiatok $^{17}$ do štátneho zoznamu kultúrnych v roku 1986 (Obuchová 2009).

Bartošová et al. (2014) tak mohli identifikovat' súbor 19 ,dôležitých industriálnych budov" vybudovaných medzi rokmi 1853 a 1939, ktoré sa zachovali do roku 1989 a ktoré sa raz opät' mali dostat' do odlišných vzt'ahov produkcie a transformácie mestskej krajiny (obr. 3). Boli to: tabaková továreň, 1. železničná stanica, Kühmayerova továreň/7. mlyn, Rothova továreň (Patrónka), pivovar Stein, Grün-

\footnotetext{
${ }^{14}$ Za najvýznamnejšie príklady „socialistickej“ industrializácie Bratislavy môžeme považovat’ nástupcu zbombardovanej rafinérie, závod Slovnaft, a Bratislavské automobilové závody (BAZ). Poloha a mierka tieto podniky významným spôsobom odlišovala od historických priemyselných podnikov, ktoré vznikli v predchádzajúcich obdobiach.

${ }^{15}$ So zmenou polohy areálov priemyselnej výroby sa spájajú čoraz citlivejšie vnímané environmentálne súvislosti. Ciel'om kritiky bratislavských ochranárov sa v 80. rokoch stalo napr. Kablo - závod 02 Gumon pre úlety organických rozpúšt'adiel - benzínu, toluénu, metanolu z epoxidových živíc (MV SZOPK 1989).

${ }^{16}$ Odbor kultúry NVB, Slovenská spoločnost' pre dejiny vied a techniky SAV, Mestské múzeum v Bratislave a Československá vedeckotechnická spoločnost' (Obuchová 2009).

${ }^{17}$ Vôbec prvé technické pamiatky zaradené do štátneho zoznamu kultúrnych pamiatok boli v roku 1980 budova bývalej centrálnej železnice Viedeň - Bratislava z roku 1848 na Šancovej ulici a budova vodárne na Mudroňovej ulici z roku 1915 (Obuchová 2009).
} 
bergova továreň na kefy, Dynamit-Nobel, Ludwigov mlyn, továreň na káble (Kablo), Stollwerck-Figaro, Cvernovka, Siemens-Schuckert, Matador, Danubius, Gumon, Zimný prístav, bitúnok na Miletičovej ul., nová plynáreň a Jurkovičova tepláreň.

\section{POSTSOCIALISTICKÁ URBÁNNA TRANSFORMÁCIA A PRIEMYSELNÁ KRAJINA}

Integrácia postsocialistických krajín do systému globálneho kapitalizmu, rast politického a ekonomického významu (najmä hlavných) miest a súvisiace zmeny v štruktúre ich ekonomík ovplyvnili nielen pozíciu priemyslu, ale do nových vzt’ahov postavili aj pôvodné priemyselné zóny (Kiss 2002, Temelová a Novák 2007 a Berki 2014). Napriek všeobecnému trendu poklesu významnosti priemyselnej výroby v Bratislave a jej bezprostrednom okolí (obr. 2), táto stále zohráva úlohu v ekonomickom rozvoji regiónu. Na území mesta zotrvávajú najmä v období socializmu na periférii vybudované významné priemyselné prevádzky (napr. Slovnaft a pôvodné BAZ), tiež bolo realizovaných niekol'ko projektov novej výstavby. Najvýznamnejšou z týchto investícií bolo vybudovanie výrobných a montážnych závodov Volkswagen v Devínskej Novej Vsi. V súčasnosti sa rozvoj v oblasti výstavby nových priemyselných priestorov preniesol najmä mimo administratívnych hraníc mesta. Naopak, silný priemyselný akcent socialistickej Bratislavy sa počas ostatných dvoch desat'ročí značne rozplynul najmä vo vnútornom meste, kde sú vel'ké plochy pôvodne slúžiace priemyselnej výrobe pretvárané na nové využitie. Najviditel'nejším prípadom takejto transformácie je práve územie najvýznamnejšej historickej priemyselnej zóny, kde vzniká nové mestské centrum.

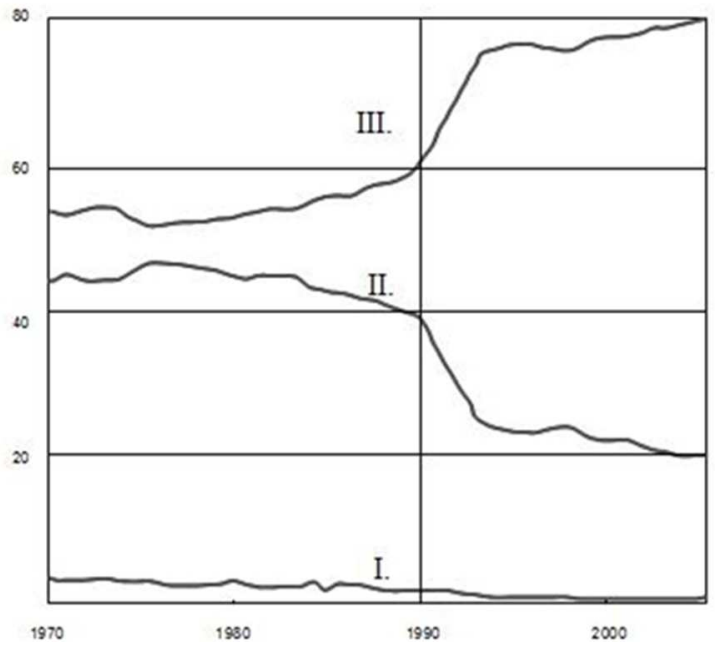

Obr. 2. Vývoj podielu zamestnanosti v sektoroch hospodárstva v Bratislave

I - pol’nohospodárstvo, II - priemysel, III - služby (podl'a Ondoš a Korec 2008).

Dosahy ekonomickej transformácie na fungovanie podnikov v historických industriálnych zónach, kde na začiatku 90. rokov minulého storočia bola stále lokalizovaná výroba, neboli vždy rovnaké, no vo výsledku znamenali koniec výroby na 


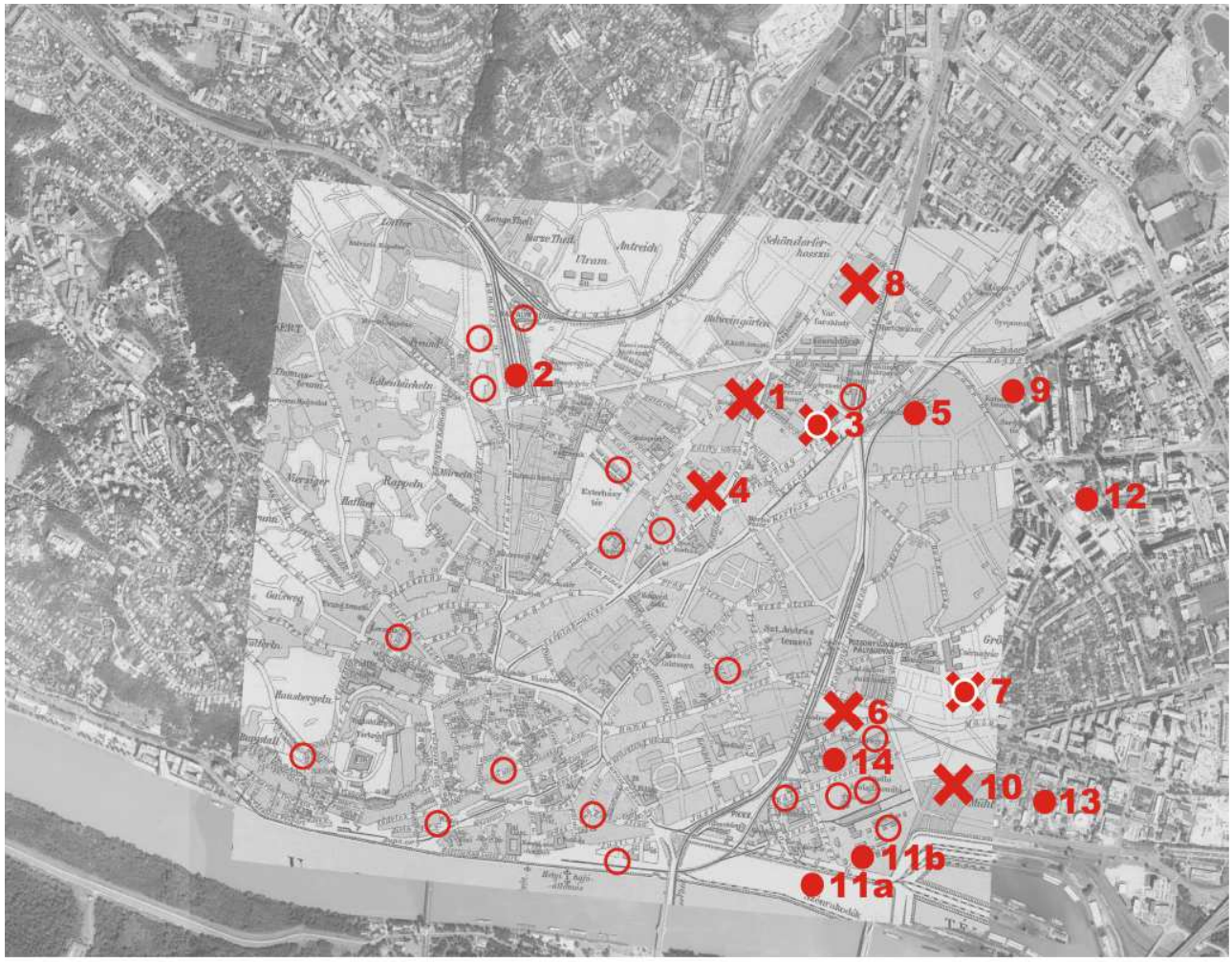

A Areály s hodnotnými budovami zbúrané po r. 1989

Areály s hodnotnými budovami čiastočne zbúrané po r. 1989

- Pamiatkovo chránené objekty historickej industrie

O Iné zdokumentované lokality tovární a technických diel (do r. 1989 nedochované)

1. Tabaková továreň, 2. Prvá železničná stanica, 3. Pivovar Stein, 4. Grünbergova továreň na kefy, 5.Ludwigov mlyn, 6. Továreň na káble (Kablo), 7. Cvernovka, 8. SiemensSchuckert, 9. Danubius, 10. Gumon, 11. Zimný prístav: a) Sklad č. 7., b) Prečerpávacia stanica, 12. Bitúnok Miletičova, 13. Nová plynáreň a 14. Jurkovičova tepláreň.

Obr. 3. Osud dôležitých industriálnych budov zachovaných do roku 1989

Mapové zdroje: Google maps, Pozsony - szabad királyi város (1910).

Výber a lokalizácia hodnotných areálov podl’a: Obuchová (2009) a Bartošová et al. (2014). 
pôvodnom mieste. Pre ekonomické t'ažkosti išla do konkurzu ako prvá v roku 1991 bratislavská Tesla, vyrábajúca okrem iného v bývalej tabakovej továrni ${ }^{18}$. Podobné osudy čakali postupne mnohé d'alšie výrobné závody. Príkladom sú prevádzky textilného priemyslu (Závody MDŽ: Cvernovka a Danubius), ktorý predstavuje jedno z odvetví, ktorého sa reštrukturalizácia dotkla zvlášt' významne (Smith et al. 2003), hoci v samotnej Cvernovke sa výroba definitívne skončila až v roku 2003. Výroba nakoniec skončila aj v prípade podnikov, ktoré prežili transformáciu a stali súčast’ou medzinárodných výrobných koncernov. V prípade pivovaru Stein v pôvodnej továrni výroba pokračovala až do roku 2007, potom sa výroba piva nesúceho toto meno premiestnila do Vyhní a pôvodná fabrika sa dostala do rúk developerov. Osamostatnenú Káblovku kúpila v roku 1992 rakúska OEKW, dcérska spoločnost' Siemensu. V roku 1998 sa podnik stal súčast'ou spoločnosti Prysmian, ktorá preniesla výrobu na Záhorie.

Či už úspešný prechod a fungovanie v nových podmienkach, alebo nie, vd'aka privatizácii priemyselných podnikov sa všetok ich nehnutel'ný majetok dostal do rúk súkromných investorov ${ }^{19}$. Táto skutočnost' sa tiež podpísala pod osudy historických budov v priemyselných areáloch. V januári 2008 bola v areáli Kablo počas víkendového búrania strhnutá za pamiatku navrhnutá, a teda do rozhodnutia aj chránená historická kotolňa zo začiatku 20. storočia. V júli 2008 nečakane a bez povolenia zničili najstaršiu a jedinú pamiatkovo chránenú čast’ závodu Gumon lisovňu bakelitu z roku 1911. Podobne ako v prípade Kabla, investor sa nakoniec vyhol i plateniu pokuty. Uhorská král’ovská tabaková továreň na Radlinského, resp. jej čast' - tabakový sklad z polovice 19. storočia bol pamiatkovo chránený až do roku 2007. Investor v roku 2006 neuspel so žiadost'ou o zrušenie ochrany, no po požiari v roku 2007 bol zo zoznamu vyradený a neskôr v roku 2010 zbúraný. Budovy v areáli podniku Danubius Elektrik na Račianskej ulici boli sčasti zbúrané v roku 2007, v roku 2013 úplne. Vo februári 2008 sa začalo s búraním Mlyna a pekárne Jedl'a na Račianskej ulici z medzivojnového obdobia, v roku 2008 boli zbúrané budovy niekdajšej Grünbergovej továrne na kefy. Hospodárska kríza iba na čas prerušila záujem kapitálu o výstavbu, ktorej v zastavaných oblastiach musí predchádzat' búranie. V Cvernovke sa búralo postupne od roku 2012, zachovaná zostala pamiatkovo chránená budova pradiarne, no zániku sa nevyhol najstarší objekt - farbiareň z roku 1903; v Steine v lete 2014, pričom zostala zachovaná iba budova kvasiarne zo 40. rokov, no viacerým starším budovám sa privilégia ochrany nedostalo. V roku 2014 oň prišla aj budova petržalskej smaltovne.

Druhou stranou mince úpadku priemyselnej výroby $\mathrm{v}$ historických zónach je rastúci záujem o tieto lokality vo vzt’ahu s novým ekonomickým využitím. Zmeny na strane dopytu po mestskom priestore vyplývajúce zo zmien v pozícii Bratislavy v priestorovej del'be práce sú vyjadrené najmä terciarizáciou miestnej ekonomiky. Takáto zmena so sebou prináša i odlišné nároky na vybudované prostredie. Dopyt po centrálne položených lokalitách s možnost'ou novej výstavby spôsobil, že po-

\footnotetext{
${ }^{18}$.Pre značné investície do výpočtovej techniky sa podnik zadlžil a v roku 1991 z rozhodnutia MH SR prešla TESLA Bratislava do likvidácie, ako prvý podnik na Slovensku po roku 1989. Viac na: http://teslabratislava.webnode.sk/.

${ }^{19}$ Procesy politickej a ekonomickej integrácie významným spôsobom ovplyvňovali aj štruktúru kapitálu realizujúceho sa v bratislavskej výstavbe. Na začiatku 90. rokov to boli hlavne domáce spoločnosti podnikajúce v stavebníctve, ktoré sa z dôvodu absencie významnejších objednávok rozhodli realizovat' vlastné projekty, prevažne vo sfére rezidenčnej výstavby (Otyk, Slovak-Sol, Cresco a Zipp). V druhej polovici desatročia pritiahla pomaly rastúca dynamika v oblasti bratislavskej výhl'adovej zástavby záujem domácich finančných skupín, ktoré pôvodne uspeli v iných sférach. Až koncom 90 . rokov dochádza k príchodu prvých zahraničných investorov, ktorý sa z prvých nesmelých počinov zmenil na inváziu (Kremský 2010).
} 
zemky pod historickými fabrikami sa stali jednými z najhodnotnejších v meste. Okrem výstavby komerčných nehnutel'ností sa postupne presadzuje aj výstavba rezidenčná, ktorej praje najmä pokrízové oživenie realitného trhu spojené s prebiehajúcou rehabilitáciou mestského bývania (Novotný 2016 a Novotný a Pregi 2017). V jadre továrenskej štvrte sa začalo s výstavbou obytných veží od Zahy Hadid, cez cestu od nich stoja dve veže Panorama city s viac ako 600 bytmi, dominantnú rezidenčnú funkciu bude mat' nová Cvernovka, súbory na mieste niekdajšieho Gumonu, pivovaru Stein či tabakovej továrne. Inými slovami, pokles pôvodných úžitkových hodnôt priemyselných areálov vznikal aj vo vzt’ahu s rastom potenciálneho zhodnotenia územia inými funkciami. Vzniknutý rozdiel medzi realizovanými a potenciálne možnými výnosmi z lokality, alebo ,rent gap“ (Smith 1996), od istého momentu začal významne stimulovat' investičnú aktivitu v predmetnom priestore. Smith pri formulácii teórie pôvodne uvažoval v rámcoch gentrifikácie spojenej so zásadnou zmenou fyzických atribútov vybudovaného prostredia, ktorú spúštajú rozdiely medzi realizovanou a potenciálnou rentou pri nezmenenom využití (rezidenčnej funkcii). V jednej z reakcií na pôvodnú koncepciu Sýkora (1993) definoval jej špeciálnu podobu tzv. functional gap. Tu ide o zvláštnu situáciu, kde potenciálny rozdiel vo výnosoch určuje odlišné využitie existujúceho vybudovaného prostredia. Jeho argument vznikol na príklade adaptácie pôvodných priemyselných zón vnútornej Prahy na iné komerčné (obchodné) účely na začiatku 90. rokov, ked' rent gap nedosahoval dostatočnú mieru na to, aby stimuloval investičné objemy nevyhnutné na zásadnú prestavbu, resp. novú výstavbu. V súčasnej Bratislave sme svedkami situácie, ked' spomínaný rozdiel nadobudol také rozmery, že ani nevyhnutnost' investícií, ktorých agregovaný objem sa počíta rádovo v miliardách eur, nepredstavuje prekážku komplexnej transformácie lokality.

$\mathrm{V}$ kontexte takto určených ekonomických hodnôt zostáva mimoekonomické donútenie, resp. inštitucionálne priznanie a ochrana mimoekonomických hodnôt ako jediná možnost' zachovania vybraných priemyselných štruktúr. Okrem vlastnej pamiatkovej ochrany tu treba uvažovat' aj všeobecných nástrojoch územného plánovania a regulácie výstavby. Napriek existencii legálnych nástrojov územného plánovania a regulácie sa $\mathrm{v}$ praxi stretávame $\mathrm{s}$ problémom ich uplatnenia, pričom nemožno argumentovat', že k zlyhaniam dochádza len v ojedinelých a nevýznamných prípadoch. Medzi problémy, ktoré vo výsledku nevytvárajú dostatočné kapacity na formulovanie a presadzovanie verejného záujmu $\mathrm{v}$ procesoch mestského plánovania, patrí častá absencia dostatočne podrobnej územnoplánovaciej dokumentácie a nemožnost' vynútenia jej obstarania, nejasnost' regulatívov a možnosti ich „ohýbania“ až po problémy sankcionovania rozporných či protiprávnych konaní (Suška 2014). Vo vzt’ahu k ochrane industriálneho historického dedičstva je potom dôležitá skutočnost', že táto kategória na mestskej úrovni územného plánovania reflektovaná nie je.

Značne obmedzené sú aj možnosti ochrany a zachovania prostredníctvom plošnej pamiatkovej ochrany. Priemysel sa rozvíjal za hranicami historického jadra, ktoré je tradične i v Bratislave hlavným územím plošnej pamiatkovej ochrany. Hoci ide vo všeobecnosti o už dlhodobo definovanú oblast', tlak na rozvoj si v meste vynútil isté úpravy aj $\mathrm{v}$ tejto sfére. Na posun hraníc pamiatkovej zóny doplatila napríklad budova Grünebergovej továrne na kefy. Okrem inštitucionálnej podrozvinutosti nástrojov územného plánovania a regulácie výstavby zohralo pri snahách o záchranu industriálu určitú úlohu miestne špecifické postavenie a chápanie významnosti tzv. industriálneho dedičstva, ktoré len podporilo všeobecnú uprednostňovanie vlastníckych práv a súkromného záujmu. Za všetky spomeňme len majite- 
l'ovu možnost' odopretia vstupu v súvislosti s pamiatkovým výskumom, problémy $\mathrm{v}$ procese vyhlásenia za pamiatku, pri porušení povinností v súvislosti s vlastníctvom pamiatky alebo budovy $\mathrm{v}$ procese posudzovania a $\mathrm{v}$ praxi len obmedzené postihy za jej poškodenie či zničenie. Hoci počiatky záujmu pamiatkarov o industriálne dedičstvo spadajú hlboko do 20. storočia, v období postsocialistickej transformácie sa na túto tému výraznejšie nereflektovalo (Obuchová 2009). Práce na vytvorení komplexnej metodológie, ako i vytypovanie konkrétnych lokalít, sa znovu obnovili až po prvej vlne deštrukcie spojenej s predkrízovým stavebným rozmachom v Bratislave. Ministerstvo kultúry SR (MK SR) aj v reakcii na trend rýchleho úbytku priemyselných areálov zažiadalo v máji 2007, aby sa do Plánu hlavných úloh Pamiatkového úradu SR na rok 2008 dostala úloha „Spracovanie analýzy a vyhodnotenie industriálnej architektúry na území Slovenska s ciel'om navrhnút' vybrané nehnutel'nosti na vyhlásenie za národné kultúrne pamiatky, prípadne areály za pamiatkové zóny“. Malo tak íst' o ,vyrovnanie určitého dlhu zo strany ochrany kultúrnych pamiatok voči obdobiu, ktoré iné spoločensko-historické disciplíny intenzívne skúmajú, ako aj nadviazanie na prístup vyspelých európskych štátov $\mathrm{k}$ vlastnému priemyselnému dedičstvu, jeho ochrane, prezentácii a novému využitiu“ (PÚ SR 2012, p. 56). Odvtedy sa udiali viaceré zmeny na poli inštitucionálnej pamiatkovej ochrany, pričom je otázne, či vždy v prospech zvýšenia efektivity pamiatkovej starostlivosti. Problémovou vyhliadkou nad osudom stále sa zmenšujúceho súboru potenciálnych pamiatok historického industriálu je však faktická neukončenost' debaty o jeho hodnotách a náležitých formách ochrany tejto novoustanovenej pamiatkovej kategórie.

$\mathrm{V}$ praxi mestského rozvoja dochádza $\mathrm{k}$ abstrahovaniu od mimoekonomických hodnôt, $\mathrm{v}$ nových podmienkach má hodnotu iba parcela „zbavená starej zát’aže“ (Šulcová 2009, p. 342). To, že predstavitelia spoločností realizujúcich developerské projekty v predmetnom území si nevedia predstavit' hodnotu historických priemyselných objektov dostatočne dobre ilustruje fakt, že zatial' prakticky žiadna z budov, ktorá prežila vd'aka výsade pamiatkovej ochrany, nie je ekonomicky využitá. Tiež poznáme len vel'mi málo prípadov, ked' našli budovy historického industriálu svoje efektívne využitie, pričom o úspešné konverzie sa zaslúžili skôr jednotlivci, ako by boli výsledkom systematickej snahy a strategického plánovania verejnej sféry (Bartošová 2014).

\section{ZÁVER}

Príbeh historického industriálu v Bratislave je príbehom rastúceho mesta v meniacom sa medzinárodnom kontexte. V priebehu 20. storočia štyrikrát zmenilo svoju príslušnost' $\mathrm{k}$ štátnemu útvaru, pričom $\mathrm{v}$ rôznych usporiadaniach nebola úloha priemyslu určená iba všeobecným historickým trendom transformácie štruktúry hospodárstva, no na území mesta sa prejavovali aj odlišné dôrazy na nepriemyselné a mimoekonomické funkcie $\mathrm{v}$ závislosti na pozícii, ktorú $\mathrm{v}$ tom-ktorom štátnom útvare zastávalo. Od priemyselnej revolúcie, ktorá sa $\mathrm{v}$ meste materializovala v priebehu niekol'kých dekád tak prišlo hned' k niekol'kým dôležitým transformáciám určujúcich trajektóriu urbanistického rozvoja. Významná zmena viacerých kvalitatívnych a kvantitatívnych parametrov sociálno-priestorových vzt'ahov produkujúcich mestskú krajinu na všetkých mierkových úrovniach bola okrem pôsobenia kapitálu spoluurčovaná charakterom štátneho usporiadania, ktorým sa menilo postavenie verejnej sféry, jej kapacity rozhodovat', investovat', budovat' či regulovat'. 
Rozvoj moderného priemyslu na území dnešnej Bratislavy je úzko spojený tak s komplexnou spoločenskou transformáciou a rozvojom kapitalistických výrobných vzt'ahov, ako aj so štátnymi intervenciami, ktoré si kládli za ciel' modernizovat' Uhorsko. Plánovanie ciel'ov bolo prítomné aj v období 1. ČSR, ked' mesto po dlhom čase opät' získava aj významnejšie mimoekonomické funkcie, za Slovenského štátu, ked' sa stáva hlavným mestom a najmä v období štátneho socializmu, ked' štát prakticky monopolne vstupoval do urbanizačného procesu, nielen prostredníctvom regulácie, ale aj ako aktívny budovatel'. Postsocialistické obdobie je naproti tomu charakterizované absenciou podobných ambícií, ktoré sa netýkajú len snáh aktívne sa podiel'at' na výstavbe, no tiež kapacít regulovat' privátne aktivity na tomto poli.

Základná priemyselná infraštruktúra bola spojená s rozvojom kapitalistických vzt’ahov a industriálnou revolúciou, ktoré sa na území mesta začali významnejšie presadzovat' až v druhej polovici 19. storočia. Pretrvávajúca podpora priemyslu, ktorá pretrvala až do konca obdobia štátneho socializmu, znamenala okrem iného aj zachovanie časti výrobných závodov v tradičných oblastiach a s nimi aj niektorých pôvodných budov s potenciálom pamiatkových hodnôt. Tieto však medzičasom zmenili svoju relatívnu polohu a v rámci rýchlo rastúceho mesta sa dostali na hranice jeho centra. S rastom mesta súvisia aj d’alšie zmeny, napríklad v dopravnej infraštruktúre, kde sa relatívna poloha oblasti tradičného priemyslu voči nákladnej železničnej doprave skomplikovala. V tomto období teda došlo k prvej úrovni zmien neskôr priamo vedúcich $\mathrm{k}$ rastu rozdielov medzi realizovanými a potenciálnymi príjmami z nehnutel'ností (rent gap). Jeho konštrukcia prebieha na dvoch mierkových úrovniach. Potenciál je na všeobecnej úrovni vyjadrený polohou a s ňou spojenou dostupnost'ou v rámci mesta, resp. metropolitnej oblasti, kde najvyššie výnosy sl’ubujú centrálne položené lokality. Aktuálna, resp. kapitalizovaná renta však v ovel'a väčšej miere závisí od vlastností bezprostredného okolia, teda mierkovej úrovne štvrte (Hammel 1999). Aj z tohto dôvodu aktualizácia kapitalizovanej renty prostredníctvom nového využitia vyžaduje, zvlášt' v rozl'ahlom území priemyselnej štvrte, mobilizáciu značného kapitálu, ktorý spravidla nemôže dodat' jeden investor. Nestačí teda, aby rozdiel vyprovokoval akciu jedného dobrodruha, musí stimulovat' kolektívnu akciu, ktorej výsledkom je komplexná zmena celej štvrte. To, že tento proces sa v prípade Bratislavskej historickej továrenskej štvrte práve završuje, dokladá ohlásenie budovania nadštandardných rezidenčných projektov v lokalite, ktorá je na kvalitu okolia spravidla najcitlivejšia.

Procesu komplexnej transformácie, ktorej za obet' padli aj budovy mnohými odborníkmi považované za historicky alebo kultúrne hodnotné, nezabránili ani existujúce formy mimoekonomického nátlaku. V podobnej situácii štandardne najefektívnejšími sú rôzne podoby pamiatkovej ochrany. Okrem inštitucionálnej podrozvinutosti sa na konkrétnej situácii podpisuje neukončenost' debaty o pamiatkových hodnotách, ktoré by sa mohli viazat' na historický industriál, resp. niektoré jeho časti. Samozrejme, ciel'om nie je vytvorit' predstavu esencie pamiatkových hodnôt, ktorá je nevyhnutne prítomná a v rovnakej podobe bytostne spojená s akýmkol'vek prvkom v mestskej krajine. Naopak, pri definovaní mimoekonomických hodnôt musíme vychádzat' z relačných chápaní ich podstaty. „Rozhodnutia chránit', ako chránit', čo chránit', kedy chránit’ a pod. sú politické rozhodnutia, ktoré reprezentujú hodnotové súdy" (McManus 2000, p. 106), preto konzerváciu vybudovaného prostredia, rovnako ako jeho produkciu, musíme chápat' ako proces podmienený štruktúrou a dynamikou politickej moci (Negussie 2004). Na otázky za- 
chovania hodnoty jednotlivých elementov mestskej krajiny neexistuje jediná správna odpoved', naopak, tieto sú získavané artikuláciou súčasných, rozdielne mocensky a ideologicky vyzbrojených záujmov. V súčasnosti v Bratislave kapitál vidí vyššie miery zhodnotenia $\mathrm{v}$ kreatívnej deštrukcii miesta, ktorej výsledkom je takmer dôsledné vymazanie jednej historickej vrstvy, na ktorej troskách rastie nový typ mestskej krajiny. To, že je v tomto procese len minimálne limitovaný, vypovedá o mocenskej topografii súčasnej Bratislavy.

Príspevok bol spracovaný v rámci projektu VEGA č. 2/0013/18.

\section{LITERATÚRA}

BARTOŠOVÁ, N. (2018). Fading industrial heritage of Bratislava in the urban planning context. In 5th International Multidisciplinary Scientific Conference on Social Science and Arts, SGEM 2018, Conference Proceedings, 5, pp. 105-112.

BARTOŠOVÁ, N. (2014). Priemyselné dedičstvo Dynamitky verzus tradičná pamiatková ochrana. Architektúra urbanizmus, 48, 214-235.

BARTOŠOVÁ, N., HABERLANDOVÁ, K. (2016). Industriál očami odborníkov/ pamätnikov. Bratislava (STU).

BARTOŠOVÁ, N., DULLA, M., HABERLANDOVÁ, K. (2014). Industrial architecture in Bratislava - Linking the past to the present. In Conference on Arts, Performing arts, Architecture and Design. Conference proceedings. International multidisciplinary Scientific Conference on Social Sciences \& Arts. 3 - 9 September 2014, Bulgaria. Sofia (STEF92 Technology Ltd.), pp. 747-754.

BERKI, M. (2014). Return to the road of capitalism: recapitulating the post-socialist transition. Hungarian Geographical Bulletin, 63, 319-334.

BEŇUS̆KA, M. (1982). Stavebný vývoj. In Horváth, V., Lehotská, D., Pleva, J., eds. Dejiny Bratislavy. Bratislava (Obzor), pp. 261-264.

BOKES, F. (1982). Hospodársko-spoločenská premena mesta od revolúcie 1848 do prevratu 1918 a rozmach robotníckeho hnutia. In Horváth, V., Lehotská, D., Pleva, J., eds. Dejiny Bratislavy. Bratislava (Obzor), pp. 158-214.

FEKETE, Š. (1948). Pôdorysný vývoj Bratislavy a národnostný vývoj obyvatel'stva. In Fiala, A., ed. Slovanská Bratislava I: Sborník príspevkov k dejinám hl. mesta Bratisla$v y$. Bratislava (IV. referát ÚNV), pp. 47-60.

GOJDIČ, I., ZVEDELOVÁ, K. (2006). Tabaková továreň v Bratislave - jej vývoj, zánik či záchrana. Projekt, 4, 47-51.

HALÁS, M., DŹUPINOVÁ, E. (2007). Vývoj a priestorové rozloženie bytového fondu Bratislavy. Urbanismus a územní rozvoj, 10(2), 27-35.

HALLON, L'. (2010). Zápas slovenského a nemeckého finančného kapitálu o pozície v peňažníctve Slovenska 1939-1945. Historický časopis, 58, 37-59.

HALLON, L. (2013). Význam industrializačnej politiky Uhorska pre technický vývoj na Slovensku v období druhej priemyselnej revolúcie 1867-1918. Historické štúdie: ročenka Historického ústavu Slovenskej akadémie vied, 47, 121-148.

HAMMEL, D. J. (1999). Re-establishing the rent gap: an alternative view of capitalised land rent. Urban Studies, 36, 1283-1293.

HANUŠIN, J. (1985). Technické pamiatky Mlynskej doliny. In Schwarczová, A., ed. Technické pamiatky Bratislavy: Zborník Mestskej správy pamiatkovej starostlivosti a ochrany prírody v Bratislave, 8. Bratislava (Príroda), pp. 83-94.

HAPÁK, P. (1972). Priemyselná revolúcia a vývin miest za kapitalizmu. Historický časopis, 21, 161-187.

HARVEY, D. (1985). The urbanization of capital: studies in the history and theory of capitalist urbanization. Baltimore (John Hopkins University Press).

HARVEY, D. (1989a). The condition of postmodernity. Oxford (Blackwell).

HARVEY, D. (1989b). The urban experience. Oxford (Blackwell). 
HOLEC, R. (2011). Dejiny plné dynamitu: Bratislavský podnik Dynamit Nobel na križovatkách novodobých dejín (1873-1945). Bratislava (Kaligram).

HRNČIAROVÁ, T. (2016). Historický obraz Bratislavy a jej okolia na konci 18. storočia s dôrazom na využitie krajiny. Geografický časopis, 68, 3-24.

HROMÁDKA, J. (1933). Zemepis okresu Bratislavského a Malackého. Sväzok prvý: Bratislava. Bratislava (J. Pocisk a spol.).

HROMÁDKA, J. (1935). Zemepis okresu Bratislavského a Malackého. Sväzok druhý: Malé Karpaty, Záhorská nízina, Podunajská nižina pri Bratislave. Bratislava (J. Pocisk a spol.).

HROMÁDKA, J. (1943). Všeobecný zemepis Slovenska. Bratislava (Slovenská akadémia vied a umení).

JAROŠEK, J. (1985). Počiatky elektrotechnického priemyslu v Bratislave. In Schwarczová, A., ed. Technické pamiatky Bratislavy: Zborník Mestskej správy pamiatkovej starostlivosti a ochrany prírody v Bratislave, 8. Bratislava (Príroda), pp. 39-48.

JOHANIDESOVÄ, M. (1982). Stavebný rozvoj v druhej polovici 19. a začiatkom 20. storočia. In Horváth, V., Lehotská, D., Pleva, J., eds. Dejiny Bratislavy. Bratislava (Obzor), pp. 209-214.

KISS, E. (2002). Restructuring in the industrial areas of Budapest in the period of transition. Urban Studies, 39, 69-84.

KOHÚTOVÁ, M., VOZÁR, J. (2006). Hospodárske dejiny Slovenska 1526-1848. Bratislava (Veda).

KONG, L. (1997). Culture and capital in urban change: the constitutive relationship between development imperatives and symbolic values in Singapre's built environment. Asian Geographer, 16, 89-102.

KOREC, P. (2013). Ekonomická báza Bratislavy a jej perspektívy. In Buček, J., Korec, P., eds. Moderná humánna geografia mesta Bratislava: priestorové štruktúry, siete a procesy. Bratislava (Prif UK).

KOREC, P., SMATANOVÁ, E. (2000). Vývoj rozmiestnenia bytového fondu na území Bratislavy, zákonitosti a osobitosti tohto procesu. Geografický časopis, 52, 51-66.

KREMSKÝ, P. (2010). L'udia za slovenskými novostavbami. Eprofit.sk, [Online]. Dostupné na: http://profit.etrend.sk/biznis-pribehy/ludia-za-slovenskymi-novostavbami.html [cit. 11-08-2016].

McMANUS, P. (2000). Conservation. In Johnston, R. J., Gregory, D., Pratt, G., Watts, M., eds. The Dictionary of Human Geography, 4th edition. Oxford (Blackwell), pp. 106107.

MITCHELL, C. J. A., WAAL, S. B. de (2009). Revisiting the model of creative destruction: St. Jacobs, Ontario, a decade later. Journal of Rural Studies, 25, 156-167.

MLÁDEK, J. (1986). Vzt’ah urbanizácie a industrializácie v Slovenskej socialistickej republike. Geografický časopis, 38, 186-198.

MLÁDEK, J. (1990). Teritoriálne priemyselné útvary Slovenska. Bratislava (Univerzita Komenského).

MORAVČ́́KOVÁ, H. (2009). Monumentality in Slovak architecture of the 1960s and 1970s: authoritarian, national, great and abstract. Journal of Architecture, 14, 45-65.

MORAVČIIKOVÁ, H., TOPOLČANSKÁ, M., SZALAY, P., DULLA, M., ŠČEPÁNOVÁ, S., TOSCHEROVÁ, S., HABERLANDOVÁ, K. (2011). Bratislava atlas sídlisk. Bratislava (Slovart).

MV SZOPK (1989). Ochranca prírody, spravodaj MV SZOPK 3-4. Bratislava (MV SZOPK).

NEGUSSIE, E. (2004). What is worth conserving in the urban environment? Temporal shifts in cultural attitudes towards the built heritage in Ireland. Irish Geography, 37, 202-222.

NOVOTNÝ, L. (2016). Urban development and migration processes in the urban region of Bratislava from the post-socialist transformation until the global economic crisis. Urban Geography, 37, 1009-1029. 
NOVOTNÝ, L., PREGI, L. (2017). Selective migration of population subgroups by educational attainment in the Bratislava urban region. Geografický časopis, 69, 21-39.

OBUCHOVÁ, V. (1985). Najstaršie továrne Bratislavy alebo základný výskum technických pamiatok Bratislavy z hl'adiska pamiatkovej starostlivosti. In Schwarczová, A., ed. Technické pamiatky Bratislavy: Zborník Mestskej správy pamiatkovej starostlivosti a ochrany prírody $v$ Bratislave, 8. Bratislava (Príroda), pp. 17-26.

OBUCHOVÁ, V. (2009). Priemyselná Bratislava. Bratislava (PT Marenčin).

OBUCHOVÁ, V., MAJEROVÁ, P., PAVELKA, Š. (1985). Mapa Bratislavy s lokalizáciou významných tovární a technických diel z obdobia od polovice 19. storočia do 1 . svetovej vojny. In Schwarczová, A., ed. Technické pamiatky Bratislavy: Zborník Mestskej správy pamiatkovej starostlivosti a ochrany prírody $45 v$ Bratislave. Bratislava (Príroda), pp. mapová príloha.

OČOVSKÝ, S. (1989). Domy, byty, bývanie. Bratislava (Veda).

ONDOŠ, S., KOREC, P. (2008). The rediscovered city: a case study of post-socialist Bratislava. Geografický časopis, 60, 199-213.

OSYKOVÁ, L. (2015). Legislatívne riešenia bytovej krízy počas 1. ČSR a realizácia zákonov v praxi na príklade Bratislavy. Forum Historiae, 9, 152-165.

PLEVA, J. (1982). Bratislava po oslobodení. In Horváth, V., Lehotská, D., Pleva, J., eds. Dejiny Bratislavy. Bratislava (Obzor), pp. 279-305

POZSONY - szabad királyi város (1910). [Online]. Dostupné na: https:// commons.wikimedia.org/wiki/File:Pozsony-1910.jpg [cit. 22-02-2017].

PROVAZNIK, D. (1982). Ekonomický charakter mesta do roku 1929 a sociálna štruktúra obyvatel'stva. In Horváth, V., Lehotská, D., Pleva, J., eds. Dejiny Bratislavy. Bratislava (Obzor), pp. 219-223.

PÚ SR (2012). Výročná správa za rok 2012. [Online]. Dostupné na: http:// www.pamiatky.sk/pamiatky/data/File/pamiatkovy_urad/Vyrocne_spravy/ Vyroc sprava PUSR 2011.pdf [cit. 22-02-2017].

SABOL, M. (2011). Významné priemyselné podniky na území Bratislavy v rokoch 1918 1938. In Medvecký, M., ed. Fenomén Bratislavy. Bratislava (ÚPN), pp. 203-229.

SCHUMPETER, J. A. (1975). Capitalism, Socialism and Democracy. New York (Harper).

SCHWARCZOVÁ, A., ed. (1985). Technické pamiatky Bratislavy: Zbornik Mestskej správy pamiatkovej starostlivosti a ochrany prírody 45 v Bratislave. Bratislava (Príroda).

SMITH, A., BUCEK, M., PICKLES, J., BEGG, B. (2003). Global trade, European integration and the restructuring of Slovak apparel exports. Ekonomický časopis, 51, 731-748.

SMITH, N. (1996). The new urban frontier: gentrification and the revanchist city. LondonNew York (Routledge).

SMITH, N. (2000). Creative destruction. In Johnston, R., J., Gregory, D., Pratt, G., Watts, M., eds. The dictionary of human geography, 4th edition. Oxford (Blackwell), pp. 119120.

SÝKORA, L. (1993). City in transition: the role of rent gaps in Prague's revitalization. Tijdschrift voor Economische en Sociale Geografie, 84, 281-293.

SÝKORA, L. (2009). Post-socialist cities. In Kitchin, R., Thrift, N, eds. International encyclopedia of human geography, 8, Oxford (Elsevier), pp. 387-395.

ŠULCOVÁ, J. (2009). Historický industriál - „stopa budúcnosti“. In Dvořáková, V., ed. Monumetourm tutela, Ochrana pamiatok, 20. Bratislava (PÚ SR), pp. 338-343.

ŠUŠKA, P. (2014). Neoliberalizmus ako ideológia, reálny neoliberalizmus a mesto: prípad Bratislava. Forum Historiae, 8, 146-165.

TEMELOVÁ, J., NOVÁK, J. (2007). Z průmyslové čtvrti na moderní městské centrum: proměny ve fyzickém a funkčním prostředí centrálního Smíchova. Geografie, 112, 315333.

WEBER, R. (2002). Extracting value from the city: neoliberalism and urban redevelopment. Antipode, 34, 519-540. 


\author{
Pavel $\breve{S} u \check{s} k a$
}

\title{
HISTORICAL INDUSTRIAL STRUCTURES IN THE CHANGING URBAN LANDSCAPE OF THE CITY OF BRATISLAVA
}

The aim of the article was to analyse the development and transformations of historical industrial structures in Bratislava. The historical industrial structures were understood as elements of the built environment which at the time of its formation had manufacturing or closely related functions (warehousing, trucking, etc.). The emergence and the following destinies of this part of the physical urban landscape were analysed through the fluctuations of the values of sites and actual built structures affected by political, economic, social and cultural changes or transformations of the city itself.

The development of modern industry in Bratislava is closely associated with a complex social transformation and development of capitalist relations as well as state intervention that aimed to modernise the country. Planning and aiming for non-economic goals were even more present during the first Czechoslovak Republic, when the city after a long time regained more significant non-economic functions. These even increased under the Slovak state when the city became the capital and during the socialist period when the state had a monopoly in the urbanisation process, not only through regulation but as well as an active builder. While economic restructuring in the West brought gradual changes in the urban landscape since the 1960 s, the economy of state socialism retained the emphasis on industrial production till its end.

The particular setting of allocation mechanisms during the period of state socialism affected the preservation of industrial functions in original locations. Pressure for changes due to the rising gap between actual and potential rent, however, was not realised until the second decade of the post-socialist transformation. Currently, we are witnessing the situation when the rent gap has acquired dimensions that even the need for investments with an aggregate volume counted in billions of euros, is not an obstacle to a comprehensive transformation of the site. In addition to general problems of identification and effective enforcement of public interest through regulatory instruments that could help to save part of potentially valuable objects, the historic industry encounters the particular issue of an unfinished debate on its heritage value, which only further contributes to the practical disappearance of this layer from the urban landscape. 